\title{
Political Corruption and Development Challenges In Nigeria
}

\author{
Imoh, Imoh-Ita, Gbenegbara, Sampson.N \\ Lecturer Dept. Of Public Administration Akwa-Ibom State Polytechnic \\ Lecturer Rivers State Polytechnic, Bori-Ogoni Nigeria
}

\begin{abstract}
Political corruption is no longer novel it has festered almost at the same rate with which the Nigeria state has evolved. This study examines political corruption and its dynamics in the legislature. The linkages between political corruption and challenges of national development were also discussed. The thesis of this paper is that corruption is the bane of Nigeria's development and that state control of the economy and the excessive regulation of the economic activities create the opportunistic behavior of political corruption. Based on this the paper suggests among others pragmatic and all encompassing reform of its political, administrative and economic operations as well as rule of law.
\end{abstract}

\section{Introduction}

In recent times, the issue of corruption, particularly in the third-world countries has attracted global attention to this end, different countries have adopted several multidimensional measures to eliminate, where possible or reduce the vice and its attendant adverse effects to the barest minimum level. These measures range from government policies to legislative enactments to curb corruption. A novel dimension to the fight against corruption is the fundamental role of the press otherwise referred to as fourth estate of realm in some climes.

\section{Definition And Meaning Of Corruption}

Corrupt acts require a minimum of two individuals from one or more communities, and either exchange or the promise of an exchange of money or services takes place; typically secret, the pact benefits the duo to the detriment of everyone else. Perhaps, owing to the fact that it has received much emphasis in the academic circles, various definitions of corruption have been put forward. Thus, the meaning ascribed to corruption varies just as the definition varies. Such definitions and meanings depend on the context in which it is used. It could denote depravity and perversion integrity through bribery or favour, or "a conscious and well-planned act by a person or group of persons to appropriate, by unlawful means, the wealth of another person or group of persons" (Aluko, 2006). Corruption can be viewed as the act of illegitimately turning power and /or authority into ready cash. Specifically, corruption involves the violation of established rules for personal gain and ready profit.

This paper identifies with some of the various definitions of corruption by some writers and authors. These include:

Shehu's (1991) definition of corruption as "the diversion of resources from the betterment of the community to the gain of individuals at the expense of the community". Corruption involves efforts to secure wealth or power through illegal means for private gain at public expense; or misuse of public power for private benefit.

Osoba (1996) adds that corruption is an anti-social behavior conferring improper benefits contrary to legal and moral norms, and which undermine the authorities to improve the living conditions of the people. In their view, Windsor and Getz (2000), defined corruption as socially impermissible deviance from some public duty or, more generally, some ideal standard of conduct. Furthermore, corruption is defined as the act of illegally diverting resources (especially financial resources) meant for the good of the citizenry in a defined geographical area by a privileged individual or a group, for personal use, presumably for self-aggrandizement. In this sense corruption means the use of public resources for the achievement of personal ends. (Aluko, 2006). Recent development in Nigeria where discoveries of stolen public funds run into billions of US Dollars and Nigerian's naira make these definitions very adequate and appropriate. The use of political offices, authority, uniforms, etc, by some people to intimidate and subdue others further in Nigeria. It occurs in different forms and has contributed significantly to the poverty and misery states of a large proportion of Nigeria's population.

\section{Political Corruption}

This takes place at the various levels of political authority. Political office holders and their collaborators who aspire to acquire or retain political power mainly perpetrate it. The means of perpetuation are political, economic or social power. The devastating impacts are on ideals and values of polity. It occurs when 
the politicians and political decision-makers entitled to formulate, establish and implement laws on behalf of the people are themselves corrupt. It also takes place when policy formulation and legislation are tailored to benefit politicians and legislators. It thus breeds increasing trend towards "clientelism", i.e. public office holders focusing on serving particular client groups linked to them by ethnic, geographical, etc, especially business ties and even religion "or other ties" (Shah and Shacter, 2004). The primary motivation is to acquire or retain political power through vote-buying; illegal act directed towards the election or defeat of a particular candidate, or the illegitimate patronage of civil service appointments (Aluko, 2006). In fact, it is being genuinely feared that businessmen have taken over governance because of their overt and covert financial contributions to political candidates and parties. Aside, political corruption is getting more rooted in Nigeria because of the private sector led economic development policies that the West and Multilateral institutions want and have forced on the country (Ishola, 2005). Political corruption is sometimes seen as similar to corruption of greed, as it affects the manner in which decisions are made. It manipulates institutions, rules of procedure, and international political arena include the use of public resources for campaigns illegal donations by organizations and individuals, vote buying, domination of the media and denying opposition parties access to the electronic media, i.e. radio, and television, by the political party in power. The biggest problem is the financing of political parties, and at the same time reducing the cost of and parties need to win elections, the more difficult it will be to minimize political corrupt practices (Ishola, 2005).

Etymologically, the word "corruption" is derived from the Latin word "corruptus", which means "to break' or 'destory'. Ifesinachi (2003) sees it as "the breaking of normal or social norms or practices". The World Bank (1997) defines corruption as "the abuse of public office for private gains. Public office is abused for private gain when an official accepts, solicits or extorts a bribe. It is also abused when private agents offer bribes to circumvent public polices and processes for competitive advantage and profit. Public offices can also be abused for personal benefit even if no bribery occurs through patronage, nepotism, theft of state assets or the diversion of state revenue".

Nye (1967) points out that corruption is "the behavior which deviates from the formal duties of a public role (elective or appointive) because of private gain regarding (personal, close family, private clique) wealth or status or violates rule against the exercising of certain "private" regarding influence". The transparency international (2006) simply sees corruption as "the dishonest or preferential use of power or position which has the result of (1997) essentially termed corruption to be "all those improper actions or transactions aimed at corrupt practices and other related offences Act, 2000 (Nigeria) sees corruption to include "Bribery, fraud and other related offences".

From the foregoing, one can deduce that corruption is that which is morally unacceptable; an act intentionally meant to place one or an organization at an advantage position over others in a system. It essentially an act that perverts the social norms, laws and moral ethos of a given society. Based on the above, it is obvious that the monster of corruption pervades every stratum of Nigeria society. It reveals itself as bribery, tribalism, nepotism, electoral fraud, embezzlement, kick back or ten percent, money laundering and fraud (419), pervision of justice among the police, the judiciary etc, and falsification of certificates, just to mention but these. Corruption in Nigeria is akin to a public liability company, which one may call "Corruption Inc., "“ operated by the ruling class and the Comprador bourgeoiissie. It is a prosperous company where most Nigerians own shares that yield appreciable dividends. In fact corruption in Nigeria takes various forms in which only a specialists in the subject can adequately explain.

However, for the purpose of our discourse, we will dwell on political corruption. According to Adeleye (2009), political corruption “is corruptocracy', a government of the corrupt by the corrupt and for the corrupt. And in that kind of government, there are no rules because anything goes". Aiyede (2006) defines political corruption as "the abuse of public or governmental power for illegitimate private advantage". (Gyekye, 2003) conceptualizes official position for personal gain or advantage. Political and unauthorized exploitation of one's political or perpetrated against a state or its agencies by a person holding an official position in pursuit of his or her own private profit". For Lipset and Lenz (2000), political corruption, "is an effort to secure wealth or power through illegal means for private benefit at public expense". Political corruption, simply put, is the use of legislative power by politicians or decision makers. i.e. government officials for illegitimate private gain. This entails the use of civil servants or bureaucracy to misuse and abuse governmental power that exists in a state for other purposes. It also involves an illegal act by an office holder which is directly related to their official duties. Socio-political corruption and corruption will be used interchangeably.

\section{Dynamics Of Political Legislative Corruption}

Under section 88 granting the legislature power of oversight over the executive arm or its agencies, the constitution reads in subsection 2(b) that such powers are exercisable for the purpose of enabling the National Assembly to 'expose corruption, inefficiency or waste in the execution of administration of laws within its legislative competence and in the disbursement of administration of funds appropriated by it'. A deeper 
reflection on this provision world reveal that the legislature of ethics, transparency and accountability, efficiency and essentially, leadership by example which would serve as spring board for a corruption-free and democratic society. However, observable trends within the legislature have revealed the contrary. While it is true that the Nigerian legislative have been involved in rule making through passage of several bills including two major anticorruption laws (Independent Corrupt Practices And Related Offences Commission, ICPC, Act 2001 and Economic Financial Crimes Commission, EFCC, Act 2002, amended 2004) as well as several oversight functions, its internal conduct and perennial allegations of corruption against its members is rather helpless. Perhaps, a highlight of some of these could help drive the point home.

In 1999, barely had the National Assembly settled down for legislative business when the lower house was rented by allegation of certificate falsification by the then speaker, Ahaji Salisu Bukhari. The speaker according to the News magazine faked certificate of the University of Toronto, and which qualified him to sit in the lower house (The News, June 6, 1999). Indeed, the report shocked the whole nation including the Presidency thereby casting shadows doubt over viability of the nascent democracy. After much controversy that involved denials and counter accusations between the speaker and the magazine, the speaker finally resigned his speakership and vacated his seat in the house when the truth eventually became blown open. In addition, he was tried and convicted by the court for fraud and forgery and sentenced to one year imprisonment or a 'ridiculous' option of fine of 2000 Naira. Despite the fact that this judgment generated sharp reactions from the public, still, he was given state pardon by the President 'the spirit of unity and national reconciliation' (see; The Punch, July 15, 1999: 1-2; July 22, 1999: 1-2; July 29, 1999:1-2 and May 25, 2000:1-2; Ogundolapo 1999:30).

The dust of the Bukhari saga had hardly settled when allegations bothering on perjury were levied against the Senate President, Evan(s) Ewerem by the Tell Magazin. Among others, he was accused of being an ex-convict having being jailed abroad for stealing; document and age falsification and indictment for financial impropriety when he was on the board of the Nigerian Airports Authority in the second republic as well as when he was governor of Imo State between 1992 and 1993. He was also accused of discrepancy in his name which reads Evan in some of his documents and Evans in some others (see, tell, August 9, 1999; The Punch August 6, 1999: 1-2). He was eventually impeached on November 18, after the senate was convinced of the allegations. Although Ewerem lost his position as senate president, he remained a member of the Senate House until the end of the first phase of the fourth republic in 2003. In addition, there were other forms of allegations against the senate in particular and the National Assembly as a whole. These included controversial jumbo furniture allowance which legislators paid to themselves; allegations of contract inflation and awards without legal agreements and the National Assembly's unilateral inflation of its own budget in 2002 among others (see The Punch, August 9, 2000: 1-2; July 25, 2000: 1-2; July 29, 2000:1-2, 16-17 and 25; July 27, 2000: 1-2; The News, August 21, 2000). Expectedly, these allegations have not gone without sharp reactions from members of the public and the executive arm with the latter setting up probe panels in some instances. It was in this rowdy and cloudy atmosphere that the first legislative term of the fourth republic was concluded in May 2003.

Then came the big bang. This was the allegation of bribery levied against the Senate President, Adolphus Wabara and other principal officers by the President in a nationwide broadcast. The president revealed that the Economic and Financial Crimes Commission (EFCC) uncovered an act by the then Minister for education, Professor Fabian Osuji who raised the sum of 55 million Naira which was used to bribe the Senate President and

In 2004, a sitting Senator, Uche Chukwumerije alleged that his colleagues in the house, Senator Arthur Nzeribe, gathered some other colleagues at his official residence on 14 January with an offer of 5 million Naira for each to mobilize and support the declaration of an emergency rule in Plateau state. However, not convinced that the allegation is worth a hearing, other senators waved it off and ask Senator Chwkwumerije to apologize to the house (see The News April 4, 2005). Also worth mentioning is the declaration by a member of the lower house, Honourable Haruna Yerima at a public gathering that some committees in the house go about collecting bribe from ministries and parastatals to induce members into taking favourable decision. He alleged further that the Chairman, House Committee on Communications does facilitate distribution of MTN recharge cards to honourable members. In his words:

Whoever tells you there is no corruption in the house is in fact corrupt. Ministers and Heads of parastatals are often to bring money so that their budgets can be passed. MTN bribes us every month. It brings recharge cards worth 7,500 naira monthly to each member (see The News, April, 4, 2005).

Ironically, rather than investigate the substance of the allegation, he was suspended for a month for using what the house termed 'unparliamentary language' and bringing the house into disrepute. All that has been done in this section is to review the trend and dimensions of corruption in the Nigeria legislative arm. Indeed, the trend is pervasive both at the level of leadership and the generality of members that hardly would a year pass by in the last seven years of democracy that the next section tries to advance some expansions for this trend and its implications for democracy in the country. 
The first Republic was also noted for corruptive tendencies as Government functionaries looted public funds with all impunity. The Federal Representative and Minister of Aviation, Kingsley O. Mbadiwe was said to have built a magnificent mansion and displayed much affluence. When he was asked the source of the wealth for such an edifice, he retorted "from sources known and unknown". Also, another prominent first republic Politician, Chief Festus S. Okotie-Eboh, who was the Minister of Finance, responded to charges of Political corruption leveled against him by quoting from the Bible as cited in the British Banks Report of 1985 "to those that have, more shall be given; from those that do not have, shall be taken even the little they have".

\section{Challenges Of Politiccal Corruption To National Development}

Corruption in Nigeria is as old as, Nigeria. It is embedded in the ethos, practices, conduct, beliefs, sayings, culture, idiosyncrasies and heritage of Nigeria. Corruption in Nigeria is a cankerworm that has, sadly, eaten very deep into fabrics of human societies.

The manifestations of corruption in Nigeria today include: contracts inflations, up-front payment by politicians for electoral positions (cash and carry politics), unjust court judgments, sacking of corrupt judges, dismissal of police and military personnel, arrest of governors outside Nigeria, collection of bribes/gratification from civil populace, arrest and trial of a former inspector General of Police and Governors by Economic and Financial Crimes Commission (an anti-graft agency), ostentations lifestyle of rulers, even admissions scam in Nigeria Higher Institutions of learning, to mention but a few.

In Nigeria, as indeed several African states, what appears to be devastating corrupt practices is the alarming phenomena of political leaders stealing billions and trillions of money which are public funds directly or through contracts awarded to personal companies without disclosure or contracts which were awarded only on paper but in the real sense of it, non-existent value, honour and misguided dignity is often ascribed to the wealthy or aristocrats in the society irrespective of the source of such wealth, that is, whether ill-gotten or otherwise, which in turn has greatly enhanced get-rich-quicks syndrome among the government officials and even their collaborators in the private sectors.

It has equally been argued that economic factor is largely responsible for corruption in the third world countries since the standard of living is so poor that every opportunity to enhance people's standard of living is often scuttled by the greedy few who have unfettered access to government resources. However, another school of thought has played down the economic factor as a cause for corruption in the third world countries since the rich few are more involved in large scale corruption by channeling for their private use what otherwise belongs to the public.

The level of corruption in a geo-political entity called Nigeria has reached a frightening height and dangerous proportion that the head of one of the vibrant anti-graft agency in Nigeria was quoted to have stated thus:

......having dealth with many corruption cases, I am inclined to suggest that public offices should be subjected to some form of psychiatric evaluation to determine their suitability for public office. The extent of aggrandizement and gluttonous accumulation of wealth that I have observed suggests to me that some people are mentally and psychologically unsuitable for public office.

She went further when she submitted that:

We have observed people's amassing public health to a point of suggesting 'madness' or some form of obsessive-compulsive psychiatric disorder.

The Transparency International (TI) in its 2009 Global Corruption Barometer report listed Nigeria among the most politically corrupt nations in the world. The reports also had it that African Countries were most largely affected by bribery. The most affected countries were Cameroon, Liberia, Serria Leone and Uganda with more than 50 percent rate, while countries like Russia, Ghana, Indonesia, Iraq, Kenya and Senegal fell within the category of Group 2, that is between 23-43 percent rate. Nigeria fell within Group 3 (between 13 and 22 percent rate) with countries like Pakistan, Ukraine etc. it is important to note that corruption though a universal problem yet it is more manifested in the developing/third world countries than the developed countries because of their devastating consequences.

Dr. Mahathir Bin Mohammad described the adverse effects of corruption in Nigeria and other developed nations as follows:

Truly corruption is the bane of Governments and countries. It increases the cost of administration and development, it delays constructions and projects, it obstructs progress of the country. Developments cannot be made and wealth for the nation and the people cannot be increased.

He posted further that, 
The reputation of the country would be badly affected and investors and entrepreneurs, whether local or foreign would avoid investing causing unemployment with all the social side effects. Businesses just cannot thrive and government revenue would be reduced. Public works cannot be implemented, undermining the construction.

As noted earlier, Nigeria was tipped to be one of the industrial nations of the world. Fifteen to twenty years has elapsed and Nigeria is still groping in the dark. Industrialization remains a hue-cry. This is principally due to one main factor: corruption. The consequences of corruption for economic development are detrimental. It reduces the impact of development assistance and provides an incentive to exploit natural resources, further depleting our environmental assets. Various Nigerians leaders, either voted into power or not, have stolen from the public treasury. The Nigeria's Corruption Busters has "estimated that more than $\$ 400$ billion was looted between 1960 and 1999 in Nigeria". Laying credence to this, the pioneer chairman of the Economic and Financial Crimes Commission (EFFCC), Mallam Nuhu Ribadu asserted that "Nigerian leaders have stolen about $\$ 500$ billion (N85trillion) within the past forty years" (This day, 2007). On his own part, Retired Justice Emmanuel Ayoola, Former Chairman of the Independent Corrupt Practices and other Related Offences Commission (ICPC), declared that "Nigeria has lost more than $\$ 3000$ billion to corrupt leaders since independence".

(The Tide 2010). It is obvious that no true sustainable national development can take place when our national wealth is being depleted and siphoned to private purse. And not until this is addressed, sustainable development in Nigeria will be a sham.

Economically, too, corruption is often responsible for the channeling of scarce public resources to corruption prone sector or uneconomic white elephant projects, such as dams, power plants, pipelines and refineries at the expense of less spectacular but more necessary infrastructure projects such as schools, hospitals and roads or supply of power and water to rural areas, not to talk of giving the needed attention to areas where this wealth (oil) are being generated. The various agricultural programs embarked upon by the Nigerian leaders such as the "Farm Settlement Schemes", "Operation Feed the Nation", "Green Revolution", "Back to Land Programme", "Directorate of Food, Roads, and Rural Infrastructure", Rivers Basin Development Authorities", among others have over the years, been dripping with corruption. The net product has been the "modernization of hunger". Okorobia (2010) sadly observes that "Across the country, dubious mechanisms for acquiring individual rights to communal lands were instituted by some wealthy land speculators, serving and retired top civil servants as well as military officers. The situation was further aggravated by the "Operation Feed the Nation" (OFN) and the "Green Revolution" programmes in which some government functionaries, after laying the foundation of their future ambition of becoming big-time farmers, retired to become the main beneficiaries of these schemes, while the poor peasants they claimed to be serving were pushed to the background. In this connection, it is enlightening to note that both General Olusegun Obasanjo during whose reign the "Operation Feed the Nation" scheme and the Land Use Decree were introduced, and deposed Alhaji Shehu Shagari who launched the "Green Revolution" Programme, and several other members of their respective administrations are now the proprietors of large mechanized farms. These, they have been able to accomplish by cleverly pursuing agricultural policies that would serve their interest when they were out of office". How can Nigeria develop when the majority of its citizens are hungry? Besides, it promotes inequality and erodes macroeconomic and fiscal stability in the system. It hinders the development of fair market structures and distorts competition, thereby deterring foreign investment. With all these in place, development is not insight for the next decade in Nigeria.

Worse still, a cursory look at the resources lost to waste and leakages in the past years under review is convincing enough that free quality education at all levels is realizable in Nigeria. Education which is the heartbeat of the nation's development is virtually neglected in Nigeria. Education since independence continued to suffer low budgetary allocation and lack of a clear-cut commitment on the part of these leaders. Okecha (20080 notes that "other countries have done much better: for example, Botswana 19\%, Swaziland 24\%, Lesotho 17\%, South Africa 25\%, Cote d'Ivoire 30\%, Burkina Faso 16.7\%, Ghana 30\%, Kenya 23\%, Uganda $27 \%$, Tunisia $17 \%$ and Morocco $17.7 \%$ as at 2008. Since 1999, the only year Nigeria allocated its highest budget to Education was in 2010 with N249.08 billion representing about 12 percent. Corruption has prevented our leaders (both federal and state levels) to earmark 26 percent of their yearly budgetary allocation to education as stipulated by the United Nations Educational, Scientific and Cultural Organization (UNESCO), to address the rot in the system. Without quality education, how can we achieve sustainable development?

Political corruption erodes the rule of law and harms the reputation of and trust of the citizens in the state. Corruption widens the gap between the rich and the poor. How then can the rule of law with its three fundamental principles: Impartiality, Equality before the law and Fundamental Human Rights be realized in a country where there is no economic equality? This has led to protests, rebellion and conflicts which in turn threatens national security and affect development in its totality. A case in point is the Niger Delta struggle which is championed by the Movement of the Survival of the Ogoni people, MOSOP. They are asking for a fair 
share of the resources or wealth (oil) which they produced. In this regard, Tam David-West (2009) strongly posits that "Some few people should not grow fat when some others are dying and that we should understand that about $80 \%$ of our salaries are from oil". The various political leaders in Nigeria had been "killing the goose that lays the golden egg".

Corruption has again polarized the country into an unbalanced federation. Akpan Mike (2010) chronicles that "ever since the Gowon military government introduced state governance, the number of states has since jumped from 12 to 36 . At the moment, there are as many as 32 requests for more states already with the National Assembly". For this reason, Ken Saro Wiwa queries: Why should one ethnic nationality have five state while 70 others share one state? The military split the major ethnic groups into smaller units to enable them rob the majority ethnic groups of their oil resources (Sara Wiwa 1991). What is central to our discourse is that gap between the number of states and local government areas in the north and the south continues to widen with every exercise due to political corruption. Akpan (op cit) therefore warns this invariably, is a ticking time bomb which is bound to explode in future".

\section{Conclusion And Recommendations}

From the foregoing analysis, it is obvious that our development challenges arise from corruption in governance practices. Political corruption leads to sub-optimal allocation of what is available, scares away foreign investments, and other inflows it creates situation where everybody wants power by all means since that is the easiest and surest way to affluence in Nigeria.

Political corruption stifle private initiatives and leads to the unfortunate situation where the economy resolves around the government given the dangerous dimension of political corruption on the nation's development, there is the need for the citizens and civil society groups to be more alive in saving as watch dog for elected public office holders. The society should be reform and restructure for effective service delivery.

\section{References}

[1]. Adeleye, S., (2009): "We Run a Corruptocracy" (Interview with Adekunle Yusuf), Tell, Lagos, February, 2009. pp. 16-21.

[2]. Aiyede, R.E., (2006): "The Role f INEC, ICPC and EFFCC in Combating Corruption in Nigeria" Money, Politics and Corruption in Nigeria, Abuja: IFES-Nigeria Election Support.

[3]. Akinola, A.A., (2002): "A History of Corruption" http://en.google.search/History of Corruption in Nigeria: Retrieved 02/05/2010.

[4]. Akinnola, R., (2000): Fellow Country Men... The Story of Coup D' etats in Nigeria Lagos: Rich Consult.

[5]. Akpan, M., (2006): “Why Nigeria Has Stunted Growth” Lagos Newswatch, October 18, p. 11.

[6]. Ayoola, E.O., (2010): "Corruption" The Tide Port Harcourt. Thursday, May, 27, p.2

[7]. BBC News/World/Africa, $18^{\text {th }}$ June, 2004.

[8]. David West, T., (2009): Taking the Bull by the Horns" in zero tolerance Abuja. Vol. 4 No. 1. February, p. 24

[9]. Gyekye, K., (2003): "Political Corruption: A Philosophical Inquiring into a Moral Problem". In Duko M. (ed), Philosophy And Politics, Discourse on Values, Politics and Power in Africa. Lagos: Mathhouse Press ltd.

[10]. Ibgikiowubo, H., (2004). “TSKJ SAGA: Swiss Government Freeze \$100m Accounts” Lagos, Vanguard, December 6, pp.1-2

[11]. Keith, P.B., (1974): "soldiers and Oil: The Political Transformation of Nigeria" in Okonkwo, R. (ed). The Genesis of Corruption in Nigeria http://en.wikipedia.org/wiki Accessed 02/05/2010.

[12]. Lipset, S.M. and Lenz, S.G., (2000): "Corruption, Culture and Markets" in Lawrence, E.H. and Huntington,, S., (eds) Culture: New York. Matters Basic Books,

[13]. Nye, J.S., (1967): Corruption and Political Development: A cost-benefit analysis, The American Political Science Review, vol. 61, p.417-427.

[14]. Okorobia, A.M., (2010): "The Impact of Agricultural Mechanization on the African Peasantry: From Colonial to the Early PostColonial Era" Port Harcourt, Niger Delta Heritage Centre.

[15]. Pollister, D., (2000): “Comment and Analysis: Pennies From Heaven: Many of Nigeria's Missing Millions were Laundered through Greedy Banks in London" The Guardian, London, September, 7.

[16]. Saro-Wiwa, K.B., (1991): "Creation of States" in the Guardian, lagos $20^{\text {th }}$ July, 1991.

[17]. The Transparency International, (2006): Anti-Corruption Conventions in Africa: What Civil Society can do to make the work, Berlin, Transparency International.

[18]. The World Bank (1997): World Development Report 1997: The State in a Changing World, World Bank, Washington DC.

[19]. The Guardian Newspaper Thursday, September 17, 2009 edition pg. 12.

[20]. The Guardian Newspaper Tuesday January 5, 2010 Edition pg. 10

[21]. Irene Hors, Fighting Corruption in Developing Countries: The Role of Private Sector - published in African Security Review vol. 8 No. 5,1999 pg. 7.

[22]. Irene Hors, Fighting Corruption in Developing Countries: The Role of Private Sector - published in African Security Review Vol. 8 No. 5,1999 pg. 7.

[23]. The guardian Newspapers Tuesday February 9, 2010 edition pg. 10.ew 